\title{
Assessment of the Annual Effective dose of Bottled Mineral Waters Using Closed Can Technique
}

\author{
Hesham A. Yousef \\ Physics Department, Faculty of Science, Suez University, Suez, Egypt \\ h_yosef2013@yahoo.com
}

\section{ABSTRACT}

Water is the most important substance for life. Mineral waters are widely used as drinking water, and so that, it is important to determine the radon levels, and its risk in drinking water for public health and radiation protection. Radon concentration has been measured in the bottled natural mineral water samples commercially available in the Egyptian local market, using closed can technique. Radon concentration in water samples ranged from $0.93-6.89 \mathrm{Bql}^{-1}$ and total annual effective dose ranged from $3.49-25.93 \mu \mathrm{Svy}^{-1}$. The results indicate that radon concentrations in water samples lower than the recommended limit $11.1 \mathrm{BqL}^{-1}$ by EPA, and the annual effective dose of the samples are lower than the permissible international limit by EPA and $\mathrm{WHO}$. The obtained results indicate that there is no significant public radiological risk related to radon ingested with drinking water in the present study.

Keywords: Radon; Drinking water; Water; Dose; CR-39

Date of Submission: 14 September, 2018

DOI: 10.24297/jap.v14i3.7768

ISSN: 2347-3487

Volume: 14 Issue: 3

Journal: Journal of Advances in Physics

Website: https://cirworld.com

This work is licensed under a Creative Commons Attribution 4.0 International License. 


\section{INTRODUCTION}

Radon is the main source of natural radiation exposure. Radon is a naturally occurring radioactive element. It is a colourless, odourless and chemically inert gas and has no taste. It can only be measured with special equipment. Radon is also fairly soluble in water and organic solvents $[1,2,3]$.

Assessment of natural radioactivity in drinking water has been done in different countries, to determine the risk resulting from consuming water, because it used for drinking, irrigation, swimming, and some industries. Natural water is a chemical system contains in its composition some group of gases, mineral, and organic materials. Consumers choose this alternative because they dislike the taste of chlorinated tap water $[4,5]$. Radionuclides values in water pose a number of health hazard, especially when these radionuclides are deposited in the human body through drinking. Dissolved radionuclides in water emit radon, which gradually affect living tissues, because the radon derived from ingested water penetrate inside the body.

Ground water contains different amounts of dissolved radioactive materials from the radionuclides, which found in the earth. The quantity of radionuclides in ground water change by some parameters of magnitude and is in flounced by physical, chemical and geological properties of the aquifer [6]. The distribution of radioactivity in water depending on the local geological characteristics of the source, soil, rock and other parameters that control the distribution of radionuclides in ground water and the hydrogeological condition and the geochemistry of radionuclides [4, 7, 8, 9]. Ground and surface waters contain radionuclides as natural components. Radon emitted from into waters as a result of natural processes like the decay of its parent nuclide radium [10]. The geological sources of natural mineral waters are known as aquifers, which may be of different types, and they vary greatly in terms of their depth, horizontal extent, composition, and permeability. Water filtering into the underground flow slowly through deep permeable rocks and sediments and diffuses into the empty interstitial space of the rocks [11].

Natural mineral water differs, in its original purity and its content from treated water what we drink. The surface and ground fresh water sources undergo a treatment process (settlement, filtration, precipitation, purification). During these appropriate treatments for meeting specific bacteriological and chemical safety standards, the possibility radionuclides are retained $[12,13]$. Last years, consumption of bottled mineral water has widely increased in the world, and it has become very popular. The evaluation of the radiological quality for bottled mineral drinking waters is important to reduction radiation exposure of the population. The National Research Council [14] has estimated that about $30 \%$ of radon concentration in the stomach was integrated into the walls of the stomach. The main health risk from radon is caused directly to the stomach.

This work aimed to determine radon concentration, and the annual effective doses of bottled mineral waters, which available in the Egyptian local markets. The present study represents useful monitoring data for radioactivity quality for bottled waters in Egypt. The important aim from the point of view is the radiological protection of the population.

\section{MATERIALS AND METHODS:}

Fourteen samples from different kind of bottled mineral waters (Aquafina, Safi, Evian, Isis, Flo, Vera, Aqua Delta, Dasani, Baraka, Erwina, Nahl, Hayat, Nestle, Aqua Paris) commercially available for human intake were collected from the Egyptian local market as shown in Table1. The samples were measured using closed can technique with the CR-39 detector to determine the radon concentration, and annual effective dose of inhalation and ingestion.

The samples were carefully sealed in cylindrical containers of plastic with dimensions of $(9 \mathrm{~cm}$ in diameter and $19 \mathrm{~cm}$ in depth) at room temperature for 56 days. All containers were capped tightly to an inverted cylindrical plastic cover. Detector area $(1.5 \times 1.5) \mathrm{cm}^{2}$ fixed in the inverted plastic cover at the center. The samples were stored in hermetically far from the heat. Dilute acid of $\mathrm{HCl}$ with concentration $10 \mathrm{ml} / \mathrm{Litter}$ have been added to the container to prevent absorption radionuclides by the vessel walls and adjusted the $\mathrm{pH}$ number of the samples. The containers were washed with dilute hydrochloric acid and rinsed with distilled water, before it used [15]. 
The detectors were collected from the plastic containers, and chemically etched, after exposure time. The chemical etching process occurring by using sodium hydroxide solution $(6.25 \mathrm{~N}$, purity $98 \%)$ by mixing $25 \mathrm{~g}$ of sodium hydroxide in $100 \mathrm{ml}$ of distilled water to prepare the etching solution. The etching process was done in a water bath at $\left(70 \pm 1{ }^{\circ} \mathrm{C}\right.$ for $8 \mathrm{hr}$ ) [16]. Detectors were washed in distilled water, after etching and then dipped ten minutes in a $5 \%$ acetic acid solution and washed again with distilled water, then finally dried in air. Track density was determined using an optical microscope with a magnification of 400x, after etching. The background was counted and subtracted from the count of all detectors [17]. The track density was calculated using the following relation:

$$
\rho=\frac{\sum N}{n \cdot A}
$$

$\mathrm{A}$ is the field of view area, $\mathrm{n}$ is the total number of fields of views, and $\mathrm{N}$ is the total number of tracks. Radon concentration in $\left(\mathrm{Bqm}^{-3}\right)$ in air is calculated by the following relation:

$C=\frac{\rho}{K \cdot T}$

Where, $\mathrm{C}$ is radon concentration $\left(\mathrm{Bqm}^{-3}\right), \mathrm{T}$ is the exposure time, $\rho$ is the track density, and $\mathrm{K}$ is the calibration factor of the CR-39. Radon concentration in water $\left(C_{w}\right)$ was determined using the following equation:

$$
C_{W}=C_{a i r} \frac{\lambda \cdot h \cdot T}{L}
$$

Where $C_{w}$ is radon concentration in water $\left(B q^{-1}\right), C_{\text {air }}$ is a radon concentration in air $\left(B l^{-1}\right), T$ is the exposure time of detectors (day), $\lambda$ is the decay constant of radon $\left(0.1814\right.$ day $\left.^{-1}\right), \mathrm{h}$ is the distance between detector and the surface of water $(\mathrm{cm})$, and $L$ is the thickness of water inside the container $(\mathrm{cm})[15]$.

\section{The annual effective dose for the ingested of water:}

The ingestion of drinking water containing large concentrations of radon, due to increased radiation dose exposure on the stomach and ingestion of radon this due to increase the risk of stomach cancer. The annual effective dose (AED) of an individual consumer due to intake of radon from water was obtained using the following relation:

$\operatorname{AED}(\mu S v / y)=C_{w} \cdot C_{R} \cdot D_{c}$

Where, $C_{R}$ is the consumption rate of water and equal $\left(730 \mathrm{Ly}^{-1}\right)$, and $D_{C}$ is the dose conversion factor and equal $\left(5 \times 10^{-9} \mathrm{SvBq}^{-1}\right)$ for adults $[4,18,19,20,21]$. According to UNSCEAR the committed effective dose intake from radon ingestion in water is equal $10^{-8} \mathrm{SvBq}^{-1}$ for an adult, $2 \times 10^{-8} \mathrm{SvBq}^{-1}$ for children, and $7 \times 10^{-8} \mathrm{SvBq}^{-1}$ for an infant [22].

\section{The annual effective dose of radon inhalation from water:}

According to UNSCEAR [22] the AED due to inhalation of radon from water is calculated by:

$$
A E D_{\text {inh }}=C \times R \times K \times F \times P .
$$

$\mathrm{K}$ is the dose conversion factor $\left[9 \mathrm{nSvh}^{-1} /\left(\mathrm{Bqm}^{-3}\right)\right], \mathrm{F}$ is the radon equilibrium factor $0.4, \mathrm{R}=\mathrm{C}_{\mathrm{a}} / \mathrm{C}_{\mathrm{w}}$ is the transfer factor $\left(10^{-4}\right)$, and $\mathrm{P}$ is the average indoor occupancy time per person $\left(7000 \mathrm{hy}^{-1}\right)$. The annual effective doses for inhalation and ingestion of ${ }^{222} \mathrm{Rn}$ for adults [23]. Also the annual effective doses to lung and stomach were calculated by multiplying the ingestion and inhalation doses with tissue weighting factor for stomach and lung [24]. 


\section{RESULTS AND DISCUSSION:}

Drinking water contains several natural radionuclides, for this investigation, samples of bottles mineral waters of those consumed by the population were bought from the Egyptian local market and were measured to determine the radon concentration, and annual effective doses of inhalation and ingestion of water, using closed can technique with CR-39 detector. Table 1, gives the typical of the chemical contents in $\left(\mathrm{mgl}^{-1}\right)$ of mineral water samples as shown on the labels of the samples (bottled drinking water): Calcium (Ca), Magnesium ( $\mathrm{Mg}$ ), Sodium ( $\mathrm{Na})$, Potassium $(\mathrm{K})$, Bicarbonate $\left(\mathrm{HCO}_{3}\right)$, sulphates $\left(\mathrm{SO}_{4}\right)$, Silica $\left(\mathrm{SiO}_{2}\right)$, total dissolved solids (TDS), Chlorides (Cl) and Fluorides (F). The salinity is an indicator of the concentration of the amount of dissolved salts, including calcium, magnesium, sodium and potassium [25]. The natural water contains minerals and dissolved substances. These minerals in water can be generally measured as total dissolved solids (TDS). TDS is mainly comprised of naturally occurring minerals, most inorganic salts.

In drinking water, TDS is measured as ppm or $\mathrm{mgl}^{-1}$. The TDS does not present a risk to human health, the USEPA has not set a mandatory TDS limit, but suggests a maximum level of $500 \mathrm{mgl}^{-1}$. The permissible limit of chloride $\left(250 \mathrm{mgl}^{-1}\right)$, Calcium $\left(200 \mathrm{mgl}^{-1}\right)$, Magnesium $\left(150 \mathrm{mgl}^{-1}\right)$, the permissible limit of fluoride $\left(1-1.5 \mathrm{mgl}^{-1}\right)$ in most of the groundwater samples, and sulphate permissible limit $\left(200 \mathrm{mgl}^{-1}\right)$ given by WHO and EPA [19, 26]. The values of the chemical content in all water samples are lower than the permissible limit by WHO.

Table 1. Chemical contents in $\left(\mathrm{mgl}^{-1}\right)$ of the mineral water samples as shown the labels of the samples

\begin{tabular}{|c|c|c|c|c|c|c|c|c|c|c|c|}
\hline \multirow{2}{*}{ No. } & \multirow{2}{*}{ Sample name } & \multicolumn{9}{|c|}{ Chemical content $_{\left(\mathbf{m g l}^{-1}\right)}$} \\
\cline { 4 - 12 } & & $\mathbf{C a}$ & $\mathbf{M g}$ & $\mathbf{N a}$ & $\mathbf{K}$ & $\mathbf{H C O}_{\mathbf{3}}$ & $\mathbf{S O}_{\mathbf{4}}$ & $\mathbf{S i O}_{\mathbf{2}}$ & $\mathbf{T D S}$ & $\mathbf{C l}$ & $\mathbf{F}$ \\
\hline $\mathbf{1}$ & AQUAFINA & 5.20 & 13.20 & 14.5 & 1.10 & 8.75 & 65.0 & 1.00 & 130 & 17.0 & - \\
\hline $\mathbf{2}$ & SAFI & 7.90 & 7.20 & 38.0 & 20.0 & 112.24 & 14.5 & 18.0 & 202 & 27.0 & 0.5 \\
\hline $\mathbf{3}$ & EVIAN & 80.0 & 26.0 & 6.5 & 1.00 & 360.0 & 14.0 & 15.0 & 345 & - & 0.06 \\
\hline $\mathbf{4}$ & ISIS & 4.00 & 1.92 & 86.0 & 0.70 & 53.86 & 17.5 & 9.0 & 262 & 100 & 0.04 \\
\hline $\mathbf{5}$ & FLO & 24.0 & 0.84 & 2.60 & 14.0 & 29.00 & 0.40 & 1.00 & 108 & 45.0 & - \\
\hline $\mathbf{6}$ & VERA & 16.0 & 5.00 & 42.0 & 1.70 & 26.00 & 40.0 & 3.00 & 180 & 65.0 & - \\
\hline $\mathbf{7}$ & AQUA DELTA & 28.0 & 11.04 & 43.0 & 3.80 & 195.20 & 18.0 & 28.0 & 268 & 20.0 & 0.16 \\
\hline $\mathbf{8}$ & DASANI & 25.6 & 7.20 & 14.5 & 1.80 & 119.56 & 12.0 & 12.00 & 153 & 11.0 & - \\
\hline $\mathbf{9}$ & BARAKA & 24.0 & 8.64 & 24.0 & 1.75 & 117.00 & 26.0 & 11.0 & 177 & 12.0 & - \\
\hline $\mathbf{1 0}$ & ERWINA & 12.8 & 3.84 & 26.0 & 2.00 & 97.60 & 1.50 & 24.0 & 138 & 8.80 & - \\
\hline $\mathbf{1 1}$ & NAHL & 18.4 & 7.68 & 48.0 & 0.90 & 12.20 & 47.0 & 1.45 & 226 & 89.0 & - \\
\hline $\mathbf{1 2}$ & HAYAT & 5.60 & 8.16 & 36.0 & 18.5 & 92.72 & 13.5 & 18.0 & 189 & 30.0 & 0.35 \\
\hline $\mathbf{1 3}$ & NESTLE & 16.0 & 6.72 & 16.8 & 1.30 & 80.50 & 17.5 & 9.00 & 123 & 8.00 & - \\
\hline $\mathbf{1 4}$ & AQUA PARIS & 14.4 & 7.68 & 30 & 25 & 95.16 & 10 & 18.0 & 220 & 52 & - \\
\hline
\end{tabular}

Table 2, gives the values of radon concentration of indoor radon in air $\left(\mathrm{Bqm}^{-3}\right)$ and the values of radon in water samples $\left(\mathrm{Bql}^{-1}\right)$.From the results the values of indoor radon concentration were ranged from $42.37 \pm 1.86$ to $313 \pm 5.03 \mathrm{Bqm}^{-3}$ and the values of radon concentration in water ranged from $0.93 \pm 0.04$ to $6.89 \pm 0.11$ 
$\mathrm{Bql}^{-1}$. Fig.1, represents the comparison between the values of radon concentration in the water samples. From the figure the values of Isis water sample has a high value, but Flo water sample has a low value.

The main parameters that effect of radon concentration in groundwater are the concentration of radium in bedrock and soil, rock porosity and the radon emanation. Against the threshold of $11.1 \mathrm{~Bq}^{-1}$ according to United States Environmental Protection Agency (USEPA) [26] and less than WHO action level of $100 \mathrm{~Bq}^{-1}$ [27] and under the action levels recommended by different radiological protection agencies [28]. According to USEPA the upper limit of radon content in water $11 \mathrm{Bql}^{-1}$ [29]. The values of radon concentration in water samples are within the internationally recommended safe limit of $4-40 \mathrm{~Bq}^{-1}[18]$.

Table 3, represent the values of the annual effective doses of inhalation, ingestion of water consumption, and the committed effective dose intake water for adults, children and infants and also represent the values of the annual effective doses of lung and stomach. In order to evaluate potential health hazards, doses due to ingestion of these waters were estimated to assess the contribution of these radionuclides to public exposure from radon. The annual effective doses of inhalation and ingestion varied from 0.11 to 0.78 and 3.39 to 25.15 $\mu \mathrm{Svy}^{-1}$, respectively. The summation of annual effective dose of inhalation and ingestion gives the total annual effective dose $\left(A E D_{T}\right)$, which ranged from 3.49- $25.93 \mu \mathrm{Svy}^{-1}$. The correlation relation between $\left(C_{W}\right)$ and $\left(A E D_{T}\right)$ in water as shown Fig. 2 , and the correlation factor equal $\left(R^{2}=1\right)$, this is very good correlation (positive correlation). The highest percentage of radon enters the human body from drinking water and by breathing so that we calculate the annual effective doses of stomach and lung. The annual effective dose to the stomach due to radon intakes through water consumption ranged from $406.8-3018 \mathrm{nSvy}^{-1}$, but for lung ranged from 13.2 - $93.6 \mathrm{nSvy}^{-1}$. The obtained results of AED in all studied samples were found to be lower than the recommended value $1 \mathrm{mSvy}^{-1}$ given by EPA [30]. The committed effective dose intake by ingestion water of adults, children and infants ranged from (6.79 - 50.30), (13.02 - 96.46) and (47.43 - 351.39) $\mu$ Svy $^{-1}$, respectively.

Table 2. The sample name, radon concentration in air in $\left(\mathrm{Bqm}^{-3}\right)$ and water in $\left(\mathrm{Bq}^{-1}\right)$

\begin{tabular}{|c|c|c|c|}
\hline Sample Code & Sample name & $\mathrm{C}_{\mathrm{a}}\left(\mathrm{Bqm}^{-3}\right)$ in air & $\begin{array}{c}\mathrm{C}_{\mathrm{w}}\left(\mathrm{Bq}^{-1}\right) \text { in } \\
\text { water }\end{array}$ \\
\hline$W_{1}$ & Aquafina & $47.08 \pm 1.95$ & $1.04 \pm 0.04$ \\
\hline$W_{2}$ & Safi & $80.35 \pm 2.52$ & $1.77 \pm 0.06$ \\
\hline$W_{3}$ & Evian & $43.43 \pm 1.87$ & $0.96 \pm 0.04$ \\
\hline$W_{4}$ & Isis & $313.0 \pm 5.03$ & $6.89 \pm 0.11$ \\
\hline$W_{5}$ & Flo & $42.37 \pm 1.86$ & $0.93 \pm 0.04$ \\
\hline$W_{6}$ & Vera & $75.65 \pm 2.52$ & $1.67 \pm 0.05$ \\
\hline$W_{7}$ & Aqua delta & $105.84 \pm 2.92$ & $2.33 \pm 0.07$ \\
\hline$W_{8}$ & Dasani & $65.50 \pm 2.27$ & $1.44 \pm 0.05$ \\
\hline$W_{9}$ & Baraka & $65.83 \pm 2.27$ & $1.45 \pm 0.05$ \\
\hline$W_{10}$ & Erwina & $135.15 \pm 3.33$ & $2.97 \pm 0.07$ \\
\hline$W_{11}$ & Nahl & $81.74 \pm 2.60$ & $1.80 \pm 0.06$ \\
\hline$W_{12}$ & Hayat & $83.69 \pm 2.84$ & $1.84 \pm 0.06$ \\
\hline$W_{13}$ & Nestle & $49.35 \pm 2.03$ & $1.09 \pm 0.04$ \\
\hline$W_{14}$ & Aquaparis & $129.55 \pm 3.25$ & $2.85 \pm 0.07$ \\
\hline
\end{tabular}




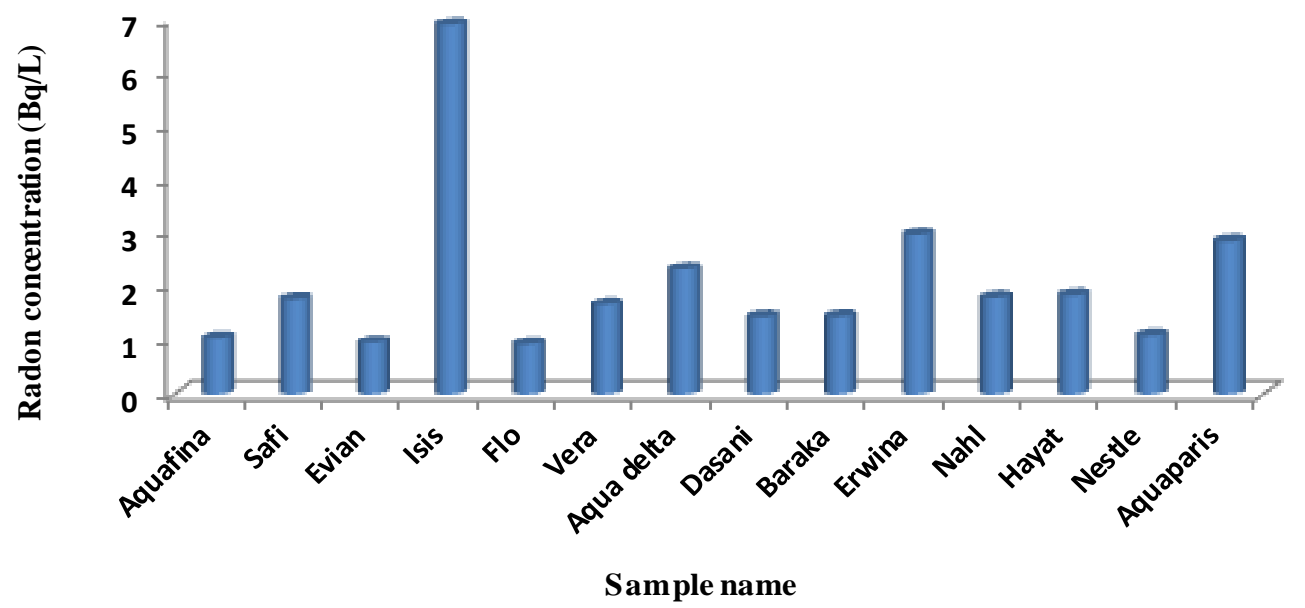

Fig.1: The relation between sample nameand radon concentration in water

Fig.3, shows that the values of committed effective dose of infant higher than children and adults. And it's equal seven times of adults and about three times of children, due to they drink more raw water in proportion to their body mass compared to adults. The overall radiation dose due to radon emanating from water was increasing with increase water consumption. The recommended level of committed effective dose is $0.1 \mathrm{mSvy}$ ${ }^{1}$ consumption of drinking water [4]. Fig.4, shows the correlation relation between $A E D_{\text {ing }}$ and $A E D_{\text {inh }}$ this is a very good correlation and the correlation factor $\left(R^{2}=0.99\right)$. There is a very good correlation relation $\left(R^{2}=1\right)$ between the annual effective dose of ingestion water and annual effective dose of stomach as shown Fig.5, and also the correlation relation between inhalation annual effective dose and lung effective dose positive relation $\left(R^{2}=1\right)$ as shown Fig.6.

Table3.The annual effective doses of inhalation, ingestion, the total annual effective dose, the committed effective dose per unit intake by ingestion water, and the effective doses of lung, and stomach

\begin{tabular}{|c|c|c|c|c|c|c|c|c|}
\hline \multirow[t]{2}{*}{$\begin{array}{c}\text { Sample } \\
\text { code }\end{array}$} & \multirow[t]{2}{*}{$\begin{array}{c}E_{i n h} \\
\left(\mu S_{v y}{ }^{-1}\right)\end{array}$} & \multirow[t]{2}{*}{$\begin{array}{c}E_{\text {ing }} \\
\left(\mu \mathrm{Svy}^{-1}\right)\end{array}$} & \multirow[t]{2}{*}{$\begin{array}{c}E_{T} \\
\left(\mu S v y^{-1}\right)\end{array}$} & \multicolumn{3}{|c|}{$\begin{array}{l}\text { Committed effective dose per } \\
\text { unit intake by ingestion water } \\
\qquad\left(\mu \mathrm{Svy}^{-1}\right)\end{array}$} & \multirow[t]{2}{*}{$\begin{array}{l}\text { Lung } \\
\left(\text { nSvy }^{-1}\right)\end{array}$} & \multirow[t]{2}{*}{$\begin{array}{c}\text { Stomach } \\
\left(\mathrm{nSvy}^{-1}\right)\end{array}$} \\
\hline & & & & Adults & Children & Infants & & \\
\hline$W_{1}$ & 0.12 & 3.80 & 3.82 & 7.59 & 14.56 & 53.04 & 14.40 & 456.0 \\
\hline$W_{2}$ & 0.20 & 6.46 & 6.66 & 12.92 & 24.78 & 90.27 & 24.00 & 775.2 \\
\hline$W_{3}$ & 0.11 & 3.50 & 3.61 & 7.01 & 13.44 & 48.96 & 13.20 & 420.0 \\
\hline $\mathrm{W}_{4}$ & 0.78 & 25.15 & 25.93 & 50.30 & 96.46 & 351.39 & 93.60 & 3018 \\
\hline$W_{5}$ & 0.11 & 3.39 & 3.49 & 6.79 & 13.02 & 47.43 & 13.20 & 406.8 \\
\hline$W_{6}$ & 0.19 & 6.10 & 6.29 & 12.19 & 23.38 & 85.17 & 22.80 & 732.0 \\
\hline$W_{7}$ & 0.27 & 8.50 & 8.77 & 17.01 & 32.62 & 118.83 & 32.40 & 1020 \\
\hline$W_{8}$ & 0.16 & 5.26 & 5.42 & 10.51 & 20.16 & 73.44 & 19.20 & 631.20 \\
\hline$W_{9}$ & 0.17 & 5.29 & 5.46 & 10.58 & 20.30 & 73.95 & 20.40 & 634.8 \\
\hline
\end{tabular}




\begin{tabular}{|c|c|c|c|c|c|c|c|c|}
\hline$W_{10}$ & 0.34 & 10.84 & 11.18 & 21.68 & 41.58 & 151.47 & 40.80 & 1301 \\
\hline$W_{11}$ & 0.21 & 6.57 & 6.78 & 13.14 & 25.20 & 91.80 & 25.20 & 788.4 \\
\hline$W_{12}$ & 0.22 & 6.72 & 6.94 & 13.43 & 25.76 & 93.84 & 26.40 & 806.4 \\
\hline$W_{13}$ & 0.12 & 3.98 & 4.10 & 7.96 & 15.26 & 55.60 & 14.40 & 477.6 \\
\hline$W_{14}$ & 0.33 & 10.40 & 10.73 & 20.81 & 39.90 & 145.35 & 39.60 & 1248 \\
\hline
\end{tabular}

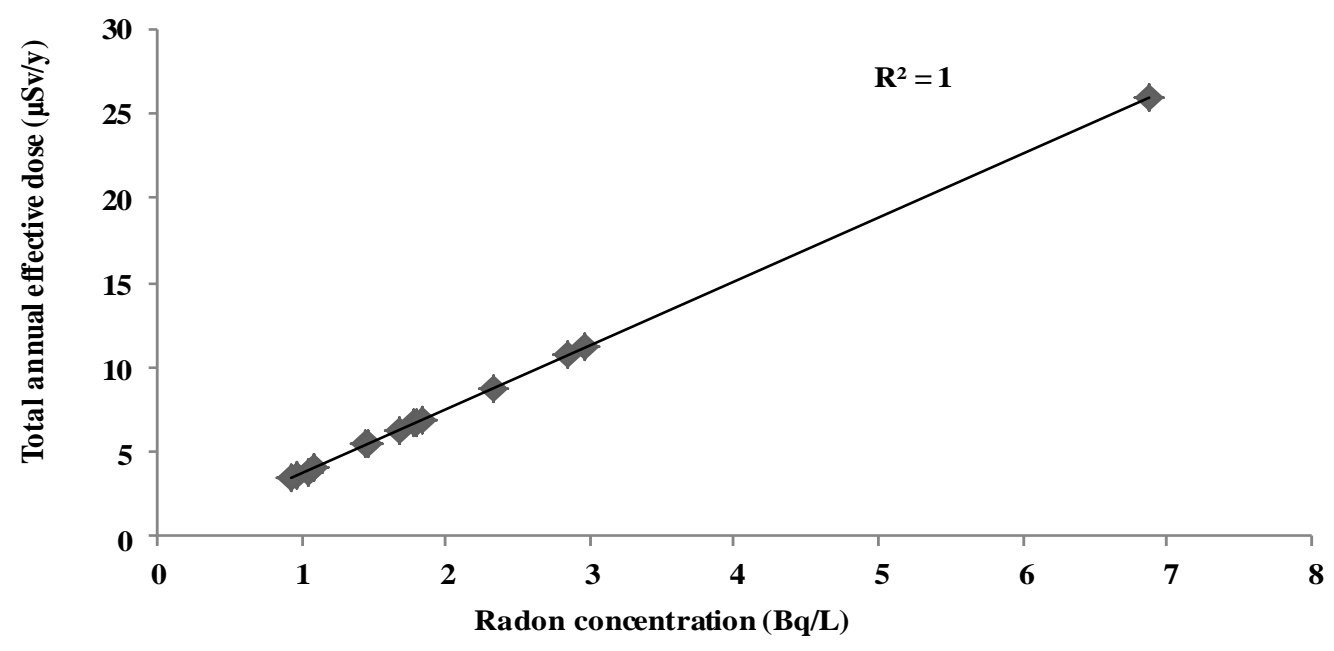

Fig.2: The correlation relation between radon concentration and total annual effective dose

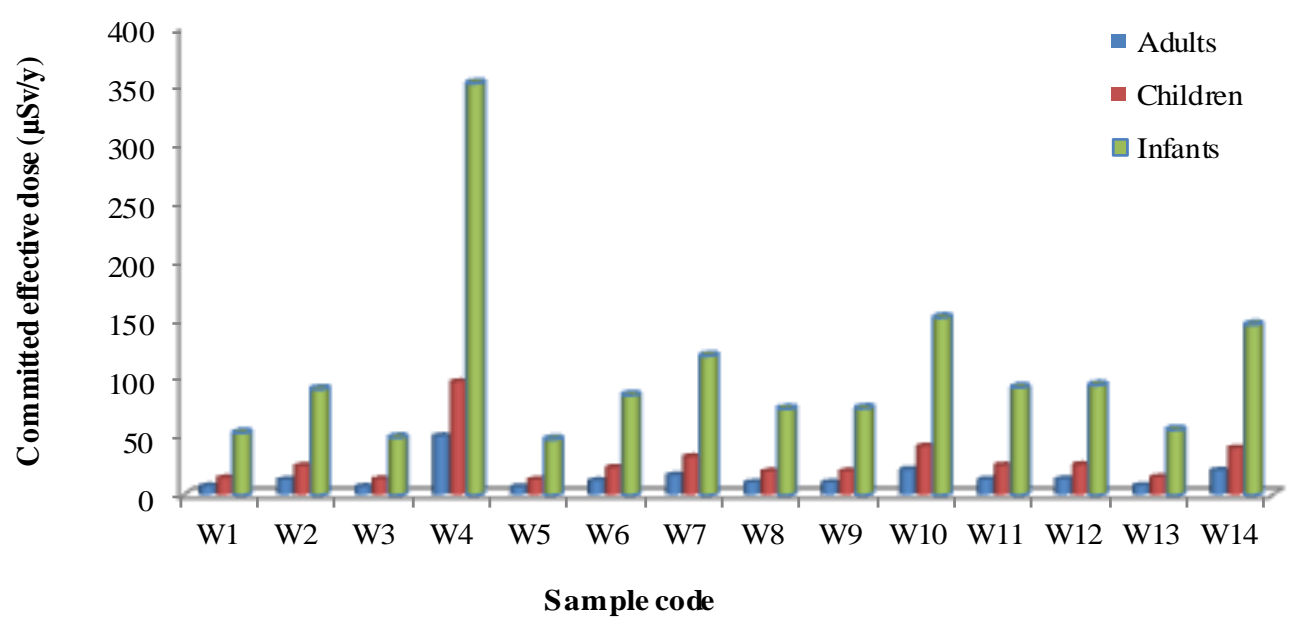

Fig.3: The comparis on between the values of committed effective dose of adults, children and infants 


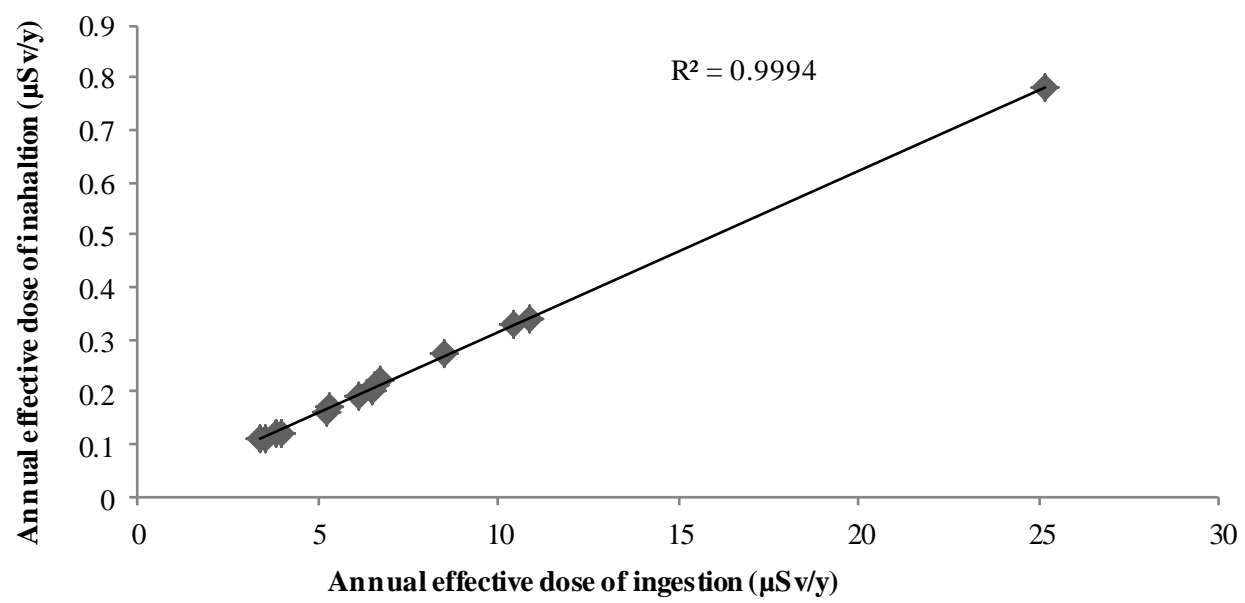

Fig.4: The correlation relation between annual effective dose of ingestion and inhalation

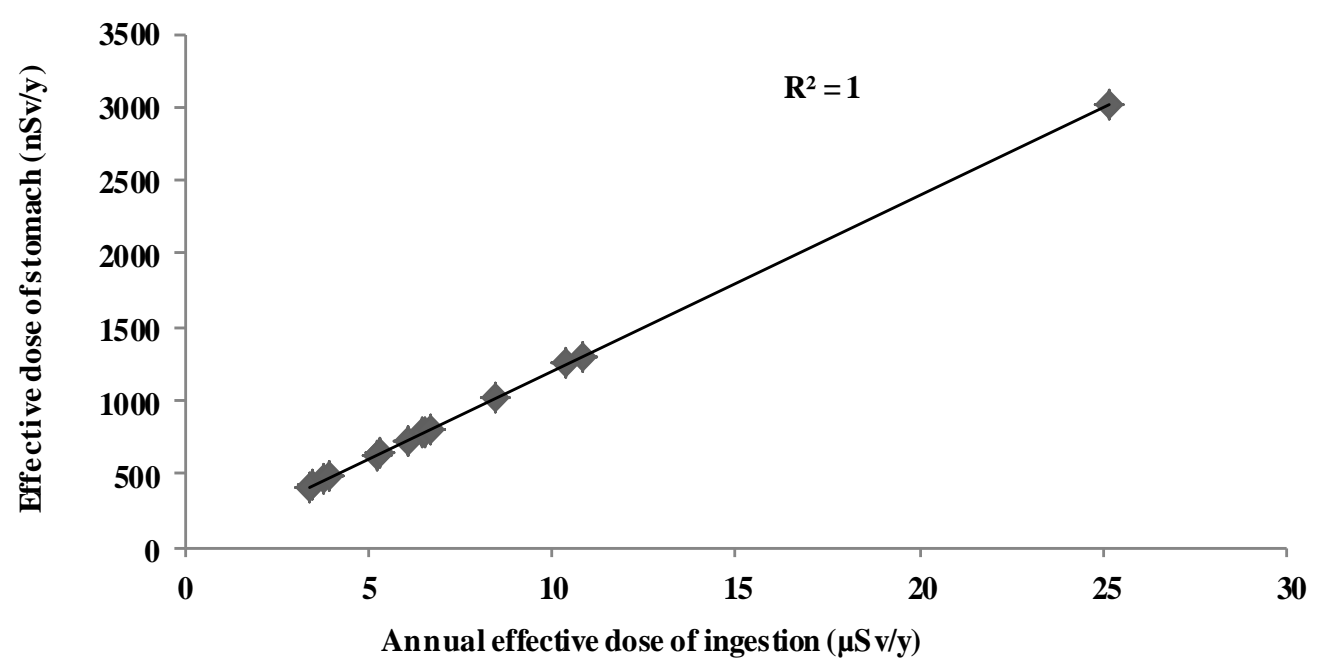

Fig.5: The correlation relation between annual effective dose of ingestion and stomach

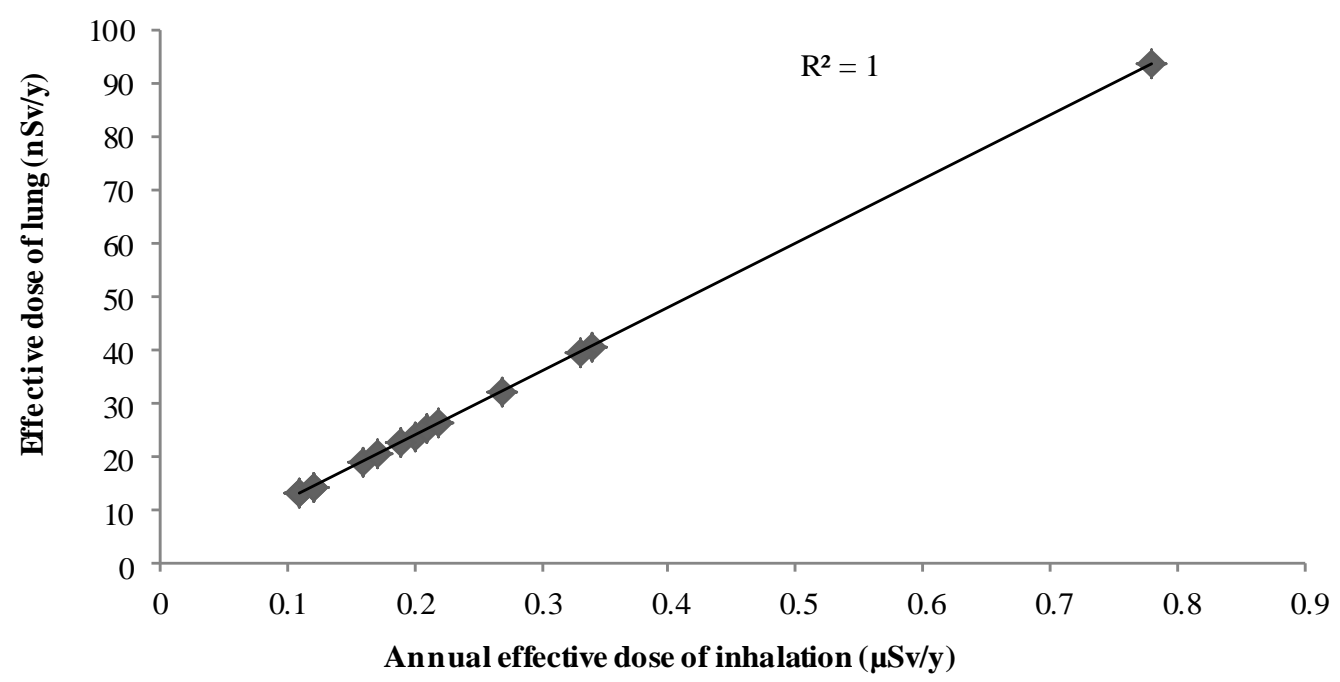

Fig.6: The correlation relation between annual effective dose and lungs 
The results of radon, and annual effective dose in drinking water of the studied samples were compared with results published from other countries, and also with the doses recommended by other relevant organizations as shown in Table 4. These results were agreement with the reported data of different authors, and were compared with the recommended safe limits for drinking water.

Table 4. Comparison between the obtained data and published results of different authors from other countries for drinking water.

\begin{tabular}{|c|c|c|c|}
\hline Countries/ Org. & $C_{R n}\left(B q l^{-1}\right)$ & AED $\left(\mu S v y^{-1}\right)$ & References \\
\hline Egypt & $2.03-6.65$ & & [31] \\
\hline Serbia & $0-3$ & & {$[32]$} \\
\hline Greece & $0.3-24$ & & [33] \\
\hline Brazil & $0.95-36.00$ & & [34] \\
\hline Turkey & $0.91-12.58$ & & [35] \\
\hline Turkey & 5.41 & & [36] \\
\hline Iraq & 2.59 & $2.27-54.26$ & [37] \\
\hline Libya & $0.93-6.60$ & $7.5-53.0$ & [38] \\
\hline Saudi Arabia & $0.92-2.12$ & & [39] \\
\hline Jordan & $2.5-4.7$ & & [40] \\
\hline Indian & $0.87-32.1$ & & [41] \\
\hline India & $1.6-5.4$ & $4.29-14.47$ & {$[42]$} \\
\hline Pakistan & $2.0-7.9$ & & [43] \\
\hline USEPA & 11 & & [26] \\
\hline EPA & 11 & & {$[44]$} \\
\hline $\mathrm{WHO}$ & & 100 & [19] \\
\hline $\mathrm{WHO}$ & 100 & & [27] \\
\hline UNSCEAR & & 100 & [22] \\
\hline Egypt & $0.93-6.89$ & $3.49-25.93$ & The present study \\
\hline
\end{tabular}

\section{CONCLUSION}

It is important to estimate the radon exposure in order to investigate the human health risk from radon concentration in drinking water. Radon concentrations were measured for bottled mineral waters (Aquafina, Safi, Evian, Isis, Flo, Vera, Aqua Delta, Dasani, Baraka, Erwina, Nahl, Hayat, Nestle, Aqua Paris) commercially available for human intake were collected from the Egyptian local market. The results showed that the radon concentration in water ranged from 0.93 to $6.89 \mathrm{Bql}^{-1}$, the obtained values of radon concentration are lower 
than the permissible limit of EPA, which equal $11 \mathrm{~Bq}^{-1}$ [44]. The highest observed value found in bottle of Isis water sample and low radon concentration was observed in a bottle of Flo water sample. The values of annual effective doses are lower than the permissible limit of WHO and ICRP $[25,45]$, and the values lower than the UNSCEAR recommended limit for members of the public, which equal $1 \mathrm{mSvy}^{-1}$ [4]. This study can be used as basic objectives the radioactivity control of the drinking mineral waters, according to existing standards and evaluation of doses to population by ingestion of mineral water. The information in this work can be used by consumers, especially those with special health needs, to make informed decisions regarding their drinking water, for estimation the dose and the resulting risk from drinking water. This work will help to establish a database radioactivity exposure to the general public from water ingestion. From the obtained results we can conclude that there is no significant radiological risk related to radon ingested with drinking water of the bottled mineral waters, and it has a good radiological quality according to the guidelines of WHO [25].

\section{REFERENCES}

1. Wallner, G., and Steininger, G., 2007. Radium isotopes and ${ }^{222} \mathrm{Rn}$ in Austrian drinking waters. Journal of Radioanalytical and Nuclear Chemistry, 274, 511- 516.

2. Joselene de Oliveiraa, Barbara Paci Mazzillia, Maria Helena de Oliveira Sampab, and Edmilson Bambalas, 2001. Natural radionuclides in drinking water supplies of Sao Paulo State, Brazil and consequent population doses. Journal of Environmental Radioactivity 53, 99-109.

3. Meghdad Pirsaheb, Kiomars Sharafi, Lida Hemati and Mehdi Fazlzadehdavil, 2015. Radon measurement in drinking water and assessment of average annual effective dose in the west region of Iran. Fresenius Environmental Bulletin, 24 (10B) 3515 - 3519.

4. United Nations Scientific Committee on the Effects of Atomic. Radiation Sources and effects of ionizing radiation. Report to the General Assembly, with Scientific Annexes, United Nations, New York, 2008.

5. Vogiannis E, and Nikolopoulos D., 2015. Radon sources and associated risk in terms of exposure and dose. Frontier in Public Health - Environmental Health, Vol., 2, Article 207, pp. 1-10.

6. Fonollosa, E., Penalver A., Borrull F., and Agular C., 2016. Radon in spring waters in the south of Catalonia. Journal of Environmental Radioactivity, 151, 275-281.

7. Nikolopoulos D, Petraki E, Marousaki A, Potirakis S, Koulouras G, et al., 2012. Environmental monitoring of radon in soil during a very seismically active period occurred in South West Greece. Journal of Environmental Monitoring, 14, 564-578.

8. National Council on Radiation Protection and Measurements (NCRP). Measurements in Radon and Radon Daughters in Air. NCRP Report 97, NCRP Publications, Bethesda MD, 1988.

9. Shivakumara B. C., Chandrashekara M.S., Kavitha E., and Paramesh L., 2014.Studies on ${ }^{226} \mathrm{Ra}$ and ${ }^{222} \mathrm{Rn}$ concentration in drinking water of Mandya Region, Karnataka State, India. Journal of Radiation Research and Applied Sciences, 7(4) 491- 498.

10. Viktor Jobbagy, Timotheos Altzitzoglou, Petya Malo, Vesa Tanner, and Mikael Hult, 2017. A brief overview on radon measurements in drinking water. Journal of Environmental Radioactivity, 173, 18-24.

11. Elena Botezatu, Olga Iacob, Angela Aflorei, Garofiţa Elisei, and Olga Căpitanu, 2001. Natural radioactivity of some mineral waters and population doses. The Journal of Preventive Medicine, 9(3) 3-14.

12. Binesh A., Mohammadi S., Mowlavi A., and Parvaresh P., 2010. Evaluation of the radiation dose from radon ingestion and inhalation in drinking water. International Journal of Water Resources and Environmental Engineering, 2(7) 174-178. 
13. World Health Organization (WHO). Guidelines for Drinking Water Quality. Recommendations. WHO Geneva, 1993.

14. National Research Council. Risk Assessment of Radon in Drinking Water. Washington D.C.: National Academy Press; 1999.

15. Hesham A. Yousef, Gehad M. Saleh, A. H. El-Farrash, and A. Hamza, 2015. Indoor radon concentration for phosphate rocks samples using CR-39 detector. International Journal of Advanced Research in Science and Technology, 4(3) 367-373.

16. Embaby A. A., Hesham A. Yousef, and Laken H. A., 2016. Estimation of radon levels in groundwater samples from graduate's villages in West Nile Delta, Egypt using alpha track detectors. International Journal of Physics and Research, 6(4)1-10.

17. Hesham A. Yousef, 2017.The annual effective dose for some food corps samples using alpha track detector. Journal of Advances in Physics, 13 (7) 5049-5053.

18. United Nations Scientific Committee on the effects of atomic radiation sources and effects of ionizing radiation, report to the General Assembly, scientific annexes. United Nation Sales Publication E.94.IX.2. United Nations, New York, 1993.

19. World Health Organization (WHO). Guidelines for Drinking Water Quality. Volume1, third Edition. Recommendations Geneva, 2004.

20. Karoly, S., Tokonami, S., Ishikawa, T., and Vancsurac, P., et al., 2007. ${ }^{222}$ Rn concentration of water in the Balaton highland and in the southern part of Hungary, and the assessment of the resulting dose. Journal of Radiation Measurements, 42, 491- 495.

21. World Health Organization (WHO). Guidelines for drinking-water quality (4th edition.), Geneva. 2011.

22. United Nations Scientific Committee on the Effects of Atomic Radiation. Sources and effects of ionizing radiation. Report to the General Assembly, with scientific annexes B. United Nations sales publication E.00.IX.3 and E.00.IX.4. United Nations, New York, 2000.

23. International Commission on Radiological Protection. ICRP Publication 119, Compendium of Dose Coefficients based on ICRP Publication 60, 2012.

24. United Nations Environment Program Global Environment Monitoring System. Water quality for ecosystem and human health. 2nd Edition, Canada, 2006.

25. World Health Organization (WHO). Guidelines for drinking-water quality. Volume 1, pages: 197-209, Geneva, 2008.

26. United States Environmental Protection Agency (EPA). Radon mitigation research. Washington: September, 1999.

27. World Health Organization (WHO). Guidelines for drinking water quality: First edition, Volume 1 , Recommendations. World health report, Geneva, 2006.

28. International Commission on Radiological Protection. Recommendations of the international committee on radiological Protection. ICRP Publication 60. Ann. Oxford: Pergamon Press, 1991.

29. United States Environmental Protection Agency (EPA). National Primary Drinking Water Regulations; Radionuclides. Proposed Rule 40 CFR Parts 141 and 142, Federal Register, Volume 56, No.138, 1991.

30. Environmental Protection Agency (EPA) regulations, Final Rule for Non-Radon Radionuclides in Tap Water, Technical Fact Sheet, EPA, 2000. 
31. Mehra R., Badhan K., and Sonkawade R.G. Radon activity measurements in drinking water and in indoors of dwellings, using RAD7. Tenth Radiation Physics and Protection Conference, 27-30 November 2010, Nasr City Cairo, Egypt.

32. Todorovic, N., Nikolov, J., Forkapic, S., Bikit, I., Mrdja, D., Krmar, M., and Veskovic, M., 2012. Public exposure to radon in drinking water in SERBIA. Journal of Applied Radiation and Isotopes, 70, 543-549.

33. Nikolopoulos D, and Louizi A., 2008. Study of indoor radon and radon in drinking water in Greece and Cyprus implications to exposure and dose. Journal of Radiation Measurements, 43, 1305-1314.

34. Marques, A.L., Santos, W., and Geraldo, L.P., 2004. Direct measurements of radon activity in water from various natural sources using nuclear track detectors. Journal of Applied Radiation and Isotopes, 60, 801-804.

35. Tarim, U. A., Gurler, O., Akkaya, G., Kilic, N., Yalcin, S., Kaynak, G., and Gundogdu, O., 2012. Evaluation of radon concentration in well and tap waters in Bursa, Turkey. Journal of Radiation Protection Dosimetry, 150 (2), 207-212.

36. Hakan Yakut, Emre Tabar, Zemine Zenginerler, Nilufer Demirci, and Filiz Ertugral, 2013. Measurement of ${ }^{222} \mathrm{Rn}$ concentration in drinking water in Sakarya, Turkey. Journal of Radiation Protection Dosimetry, 157 (3) 397- 406.

37. Abdalsattar K. Hashim and Rajaa Hussien Abd Ali, 2015. Measurement of annual effective doses of radon in plastic bottled mineral water samples in Iraq. Australian Journal of Basic and Applied Sciences, 9(5) 31-35.

38. Rafat M. Amin, 2013. Evaluation of radon gas concentration in the drinking water and dwellings of southwest Libya, using CR-39 detectors. International Journal of Environmental Sciences, 4(4), 484- 490.

39. Tayyeb, Z. A., Kinsara, A.R., and Rarid, S.M., 1998. A study on the radon concentration in water in Jeddah (Saudi Arabia) and the associated health effects. Journal of Environmental Radioactivity, 38, 97-104.

40. Al-Bataina, B.A., Ismail, A.M., Kullab, M.K., Abumurad, K. M., and Mustafa, H., 1997. Radon measurements in different types of natural waters in Jordan. Journal of Radiation Measurements, 28, 591-594.

41. Singh J, Singh H, Singh S, and Bajwa B.S., 2008. Estimation of uranium and radon concentration in some drinking water samples. Journal of Radiation Measurements, 43, 523-526.

42. Vikas Duggal, Rohit Mehra, and Asha Rani, 2013. Analysis of radon concentration in drinking water in Hanumangarh district of Rajasthan, India. Journal of Radiation Protection and Environment, 36 (2) 65-70.

43. Manzoor F, Alaamer A.S., Tahir S.N., 2008. Exposures to ${ }^{222}$ Rn from consumption of underground municipal water supplies in Pakistan. Journal of Radiation Protection Dosimetry, 130 (3) 392- 396.

44. United States Environmental Protection Agency (EPA). A citizen's guide to radon. 2009.

45. Internal Commission on Radiological Protection, Age dependent Doses to Members of the Public from Intake of Radionuclides: Part 5 Compilation of Ingestion and Inhalation Dose Coefficients. Annals ICRP publication 72, Pergamon Press, Oxford, 1996. 